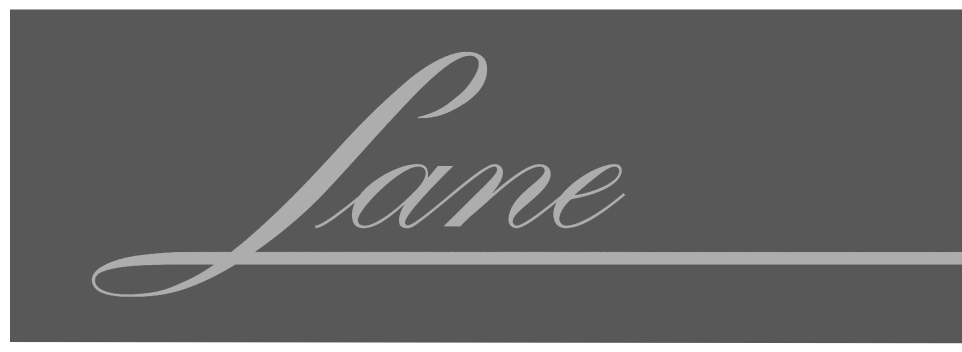

\title{
PALE ONTOLOGY
}

\section{SPECIMEN CABINETS}

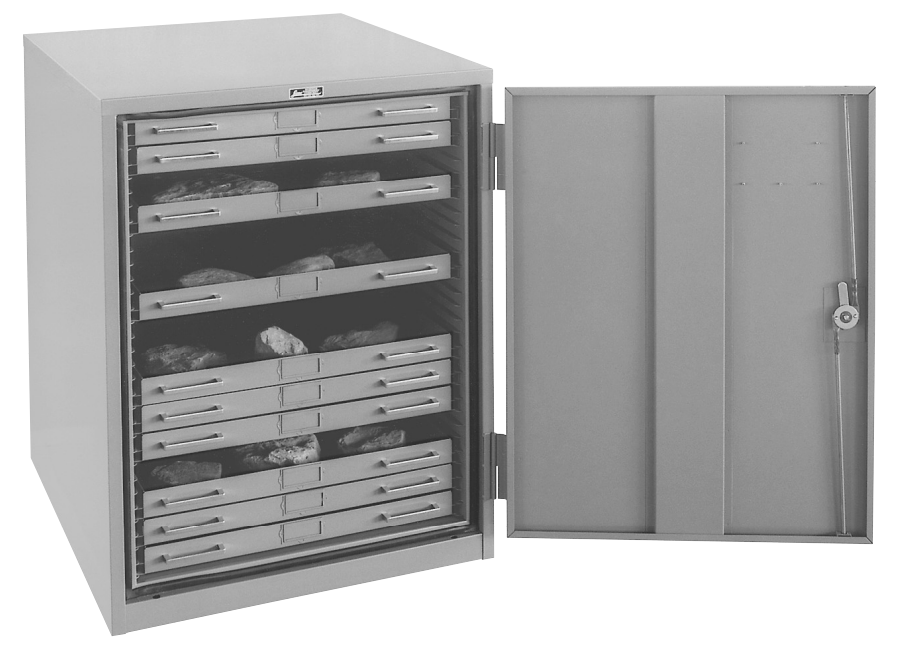

* All steel construction

Powder paint finish

Durable door seal

No adhesives

Reinforced for easy stacking

Sturdy steel trays

\section{LANE SCIENGE EQUIPMENT GORP.}

225 West 34th Street

Suite 1412

New York, NY 10122-1496
Tel: 212-563-0663

Fax: 212-465-9440

www. Ianescience.com 
https://doi.org/10.1017/jpa.2018.22 Published online by Cambridge University Press 


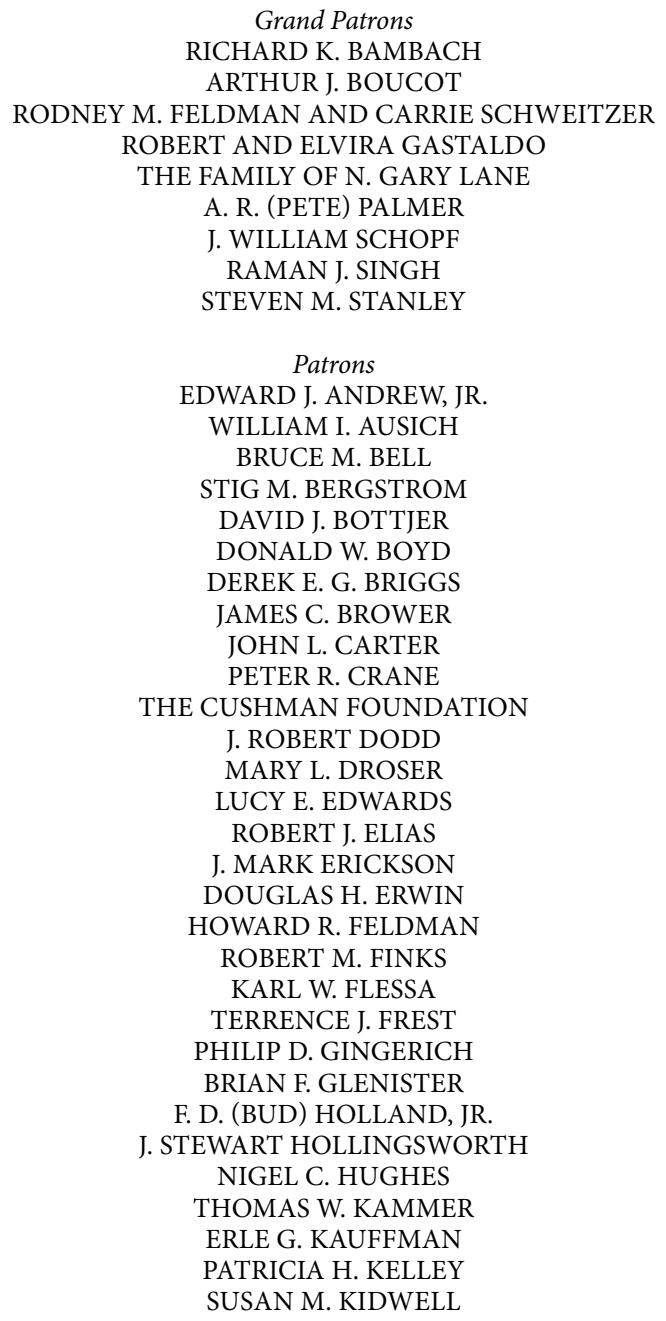

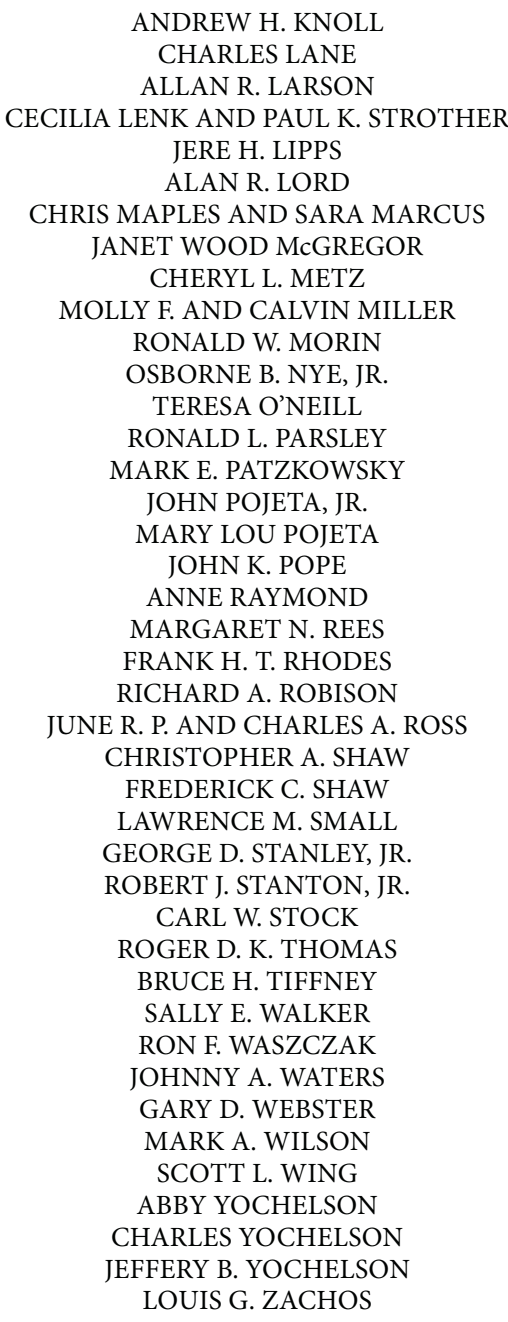

The Journal of Paleontology publishes manuscripts on all aspects of paleontology, including systematics, phylogeny, paleoecology, paleobiogeography, biostratigraphy, taphonomy, and evolution. It emphasizes specimen-based research and features illustrations of the highest quality possible. Manuscript treating all fossil organism groups are welcome, including invertebrates, vertebrates, plants, algae, and microorganisms of all sorts, as well as ichnofossils (trace fossils).

The Journal of Paleontology accepts only online manuscript submissions through the website:

https://mc.manuscriptcentral.com/paleo

Author guidelines can be downloaded at:

https://www.cambridge.org/core/journals/journal-of-paleontology/information/instructions-contributors

For questions regarding online submissions, please contact the editorial offices at:

journalofpaleontology@cambridge.org

Membership Information

Members of the Paleontological Society automatically receive electronic subscriptions to Paleobiology and the Journal of Paleontology as a benefit of membership. To apply for individual membership, please go to the Paleontological Society's homepage at http://paleosoc.org/ where links to an electronic application, a printable paper application form, and a complete list of membership benefits are provided under the Membership heading. 


\section{JOURNAL Of PALEONTOLOGY}

\section{VOL 92 | NO 3 | 2018}

313 Lily M. Reid, Diego C. García-Bellido, and James G. Gehling

An Ediacaran opportunist? Characteristics of a juvenile Dickinsonia costata population from Crisp Gorge,

South Australia

323 Marc Laflamme, James G. Gehling, and Mary L. Droser

Deconstructing an Ediacaran frond: three-dimensional preservation of Arborea from Ediacara,

South Australia

336 Daniel Vachard, Karl Krainer, and Alexander Mörtl

Middle Devonian parathuramminid and earlandiid foraminifers from shallow marine carbonates of the Carnic Alps (Austria)

373 Shiladri S. Das, Sandip Saha, Subhendu Bardhan, Sumanta Mallick, and Warren D. Allmon The oldest turritelline gastropods: from the Oxfordian (Upper Jurassic) of Kutch, India

388 Judith Nagel-Myers, Christopher A. McRoberts, and Cullen W. LaPointe

Ecophenotypic variability during times of evolutionary stasis in Middle Devonian Actinopteria (Bivalvia, Pterioidea) from New York

398 Xiang Fang, Tingen Chen, Clive Burrett, Yongsheng Wang, Yonggui Qu, Chunzi Zheng, Yunbai Zhang, Yuandong Zhang, and Wenjie Li

Middle Ordovician actinocerid nautiloids (Cephalopoda) from Xainza County, Tibet, western China, and their paleogeographic implications

412 Štěpán Manda and Vojtěch Turek

Silurian tarphycerid Discoceras (Cephalopoda, Nautiloidea): systematics, embryonic development and paleoecology

432 Leandro M. Pérez, Juan López-Gappa, and Miguel Griffin

Taxonomic status of some species of Aspidostomatidae (Bryozoa, Cheilostomata) from the Oligocene and Miocene of Patagonia (Argentina)

442 Mark Webster and Steven J. Hageman

Buenellus chilhoweensis n. sp. from the Murray Shale (lower Cambrian Chilhowee Group) of Tennessee, the oldest known trilobite from the lapetan margin of Laurentia

459 Antônio Álamo Feitosa Saraiva, Allysson Pontes Pinheiro, and William Santana

A remarkable new genus and species of the planktonic shrimp family Luciferidae (Crustacea, Decapoda) from the Cretaceous (Aptian/Albian) of the Araripe Sedimentary Basin, Brazil

466 Ninon Robin, Barry W.M. Van Bakel, Marie-Madeleine Blanc-Valleron, Pierre Y. Noël, Laurent Lemaire, and Sylvain Charbonnier

First fossil crabs (Crustacea, Decapoda, Brachyura) from the Kerguelen Islands (Miocene) with exceptionally preserved gills

478 Jinyuan Huang, Joseph T. Hannibal, Rodney M. Feldmann, Qiyue Zhang, Shixue Hu,

Carrie E. Schweitzer, Michael J. Benton, Changyong Zhou, Wen Wen, and Tao Xie

A new millipede (Diplopoda, Helminthomorpha) from the Middle Triassic Luoping biota of Yunnan, Southwest China

488 Selina R. Cole, William I. Ausich, David F. Wright, and Joseph M. Koniecki

An echinoderm Lagerstätte from the Upper Ordovician (Katian), Ontario: taxonomic re-evaluation and description of new dicyclic camerate crinoids

506 Chiara Angelone, Stanislav Čermák, Blanca Moncunill-Solé, Josep Quintana,

Caterinella Tuveri, Marisa Arca, and Tassos Kotsakis

Systematics and paleobiogeography of Sardolagus obscurus n. gen. n. sp. (Leporidae, Lagomorpha) from the early Pleistocene of Sardinia

\section{Corrigendum}

523 Judith Nagel-Myers, Christopher A. McRoberts, and Cullen W. LaPoint

Ecophenotypic variability during times of evolutionary stasis in Middle Devonian Actinopteria

(Bivalvia, Pterioidea) from New York-CORRIGENDUM

\section{Cambridge Core}

For further information about this journal please

go to the journal website at:

cambridge.org/jpa 